University for Business and Technology in Kosovo

UBT Knowledge Center

UBT International Conference

2017 UBT International Conference

Oct 28th, 4:30 PM - 6:00 PM

\title{
Habitat of Fruits Plant and Small Fruits in Maqiteva Area
}

Shkëlzim Ukaj

Hyzer Rizani

University for Business and Technology, hyzer.rizani@ubt-uni.net

Fidan Feka

Shkumbin Shala

University for Business and Technology, shkumbin.shala@ubt-uni.net

Follow this and additional works at: https://knowledgecenter.ubt-uni.net/conference

Part of the Food Science Commons

\section{Recommended Citation}

Ukaj, Shkëlzim; Rizani, Hyzer; Feka, Fidan; and Shala, Shkumbin, "Habitat of Fruits Plant and Small Fruits in Maqiteva Area" (2017). UBT International Conference. 162.

https://knowledgecenter.ubt-uni.net/conference/2017/all-events/162

This Event is brought to you for free and open access by the Publication and Journals at UBT Knowledge Center. It has been accepted for inclusion in UBT International Conference by an authorized administrator of UBT Knowledge Center. For more information, please contact knowledge.center@ubt-uni.net. 


\title{
HABITAT OF FRUITS PLANT AND SMALL FRUITS IN MAQITEVA AREA
}

\author{
Shkëlzim Ukaj, Hyzer Rizani, Fidan Feka, Shkumbin Shala
}

UBT - Higher Education Institution, Lagjja KALABRIA p.n., Prishtinë, Kosovë

10000 Prishtina, Kosovo

hyzer.rizani@ubt-uni.net

\begin{abstract}
Our country has a geographic position that enables a combination of climates, dominated by the continental climate with the influence of the Mediterranean climate that penetrates the Drini i Bardhë valley.

The purpose of the paper is to inform and motivate citizens to find fruit trees and their importance in our health as they are very rich in vitamins and minerals that enhance our biological immunity. The fruit trees of the forest have been used since ancient times especially to survive, but consuming it has been proven that some of them have relieved them during various diseases or have healed them. The most commonly used fruit plants are from the families: Rosaceae, Vaccinaceae, Corylaceae, Moraceae, etc.

After surveying and herbaceous fruit plants we conclude that their harvest is quite large and that the condition of some of the future herbs is not good due to improper collection.
\end{abstract}

Key words: Fruits of the forest, vitamins, minerals, fruit harvesting.

\section{INTRODUCTION}

Sharri Mountains are popular with many plant species. Maqiteva area as well a part of this mountain massif is rich in flora and vegetation aspect.

This enabled the variety of historical past, pedological and geological structure, climate and geographical location.

Within these species are endemic, relict and endemorelict which have great scientific importance (Adamoviç (1909), Horvat (1954),

Height on altitude of $600 \mathrm{~m}$ to $1723 \mathrm{~m}$ has enabled various types of vegetation ranging from the most up to thermophilous community to mesophillous and to the forests and subalpine flora and vegetation.

Also, the region's geographical position has enabled the research to have an impact on different climates that enable a rich flora and vegetation. 


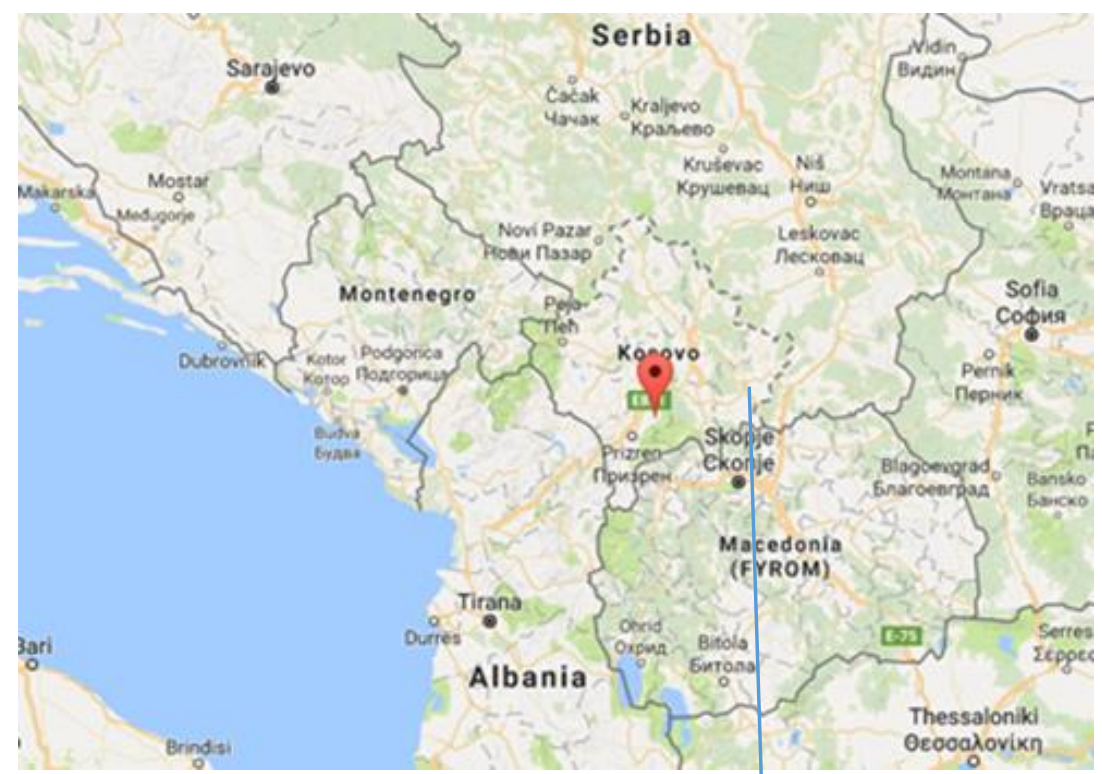

Fig. 1. The map of Southeast Europe

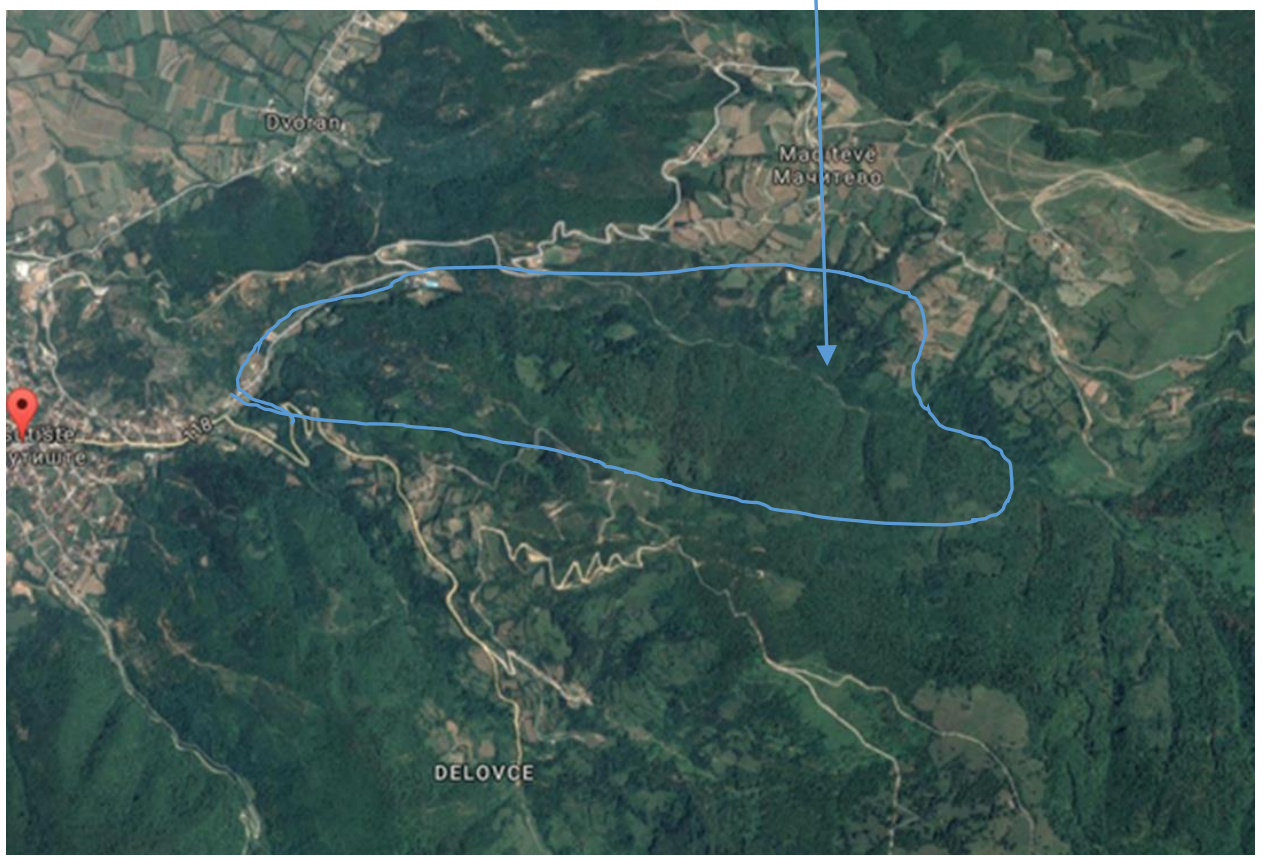

Fig. 2 Research area 


\section{MATERIAL AND METODS}

Floristic researches on the Peak of Studenica are realized in the period 2008-2017. The main part of the research was conducted during the master thesis.

Determining the species was carried out with adequate modern literature, as: Demiri, M. (1983), Josifovič, M. (1970-1986), Krasniqi, E. (2003, 2006), Lakušič, R. (1988), Millaku F. (1993, 1999), Pajazitaj Q. (2004), Rexhepi F. (1985, 1986, 1990, 1999, 2000, 2003), Paparisto, K. et al. (1988, 1992), Qosja, Xh. et al. (1996), Tutin T. G. et al. (1964-1976).

Plants were determined to systematic basic unit (species). Ordering of families, gender and species is made according to alphabetical ordering. For each plant species (in this paper) are given the following information's: species name in Latin, floral element and life form.

\section{RESULTS AND DISCUSIONS}

Found as trees, shrubs and grasses, these plant species abundantly growing in the plains of this region.

Medicinal plants have the potential to fill these needs as they provide green health alternatives and a number of other eco-friendly products of domestic and industrial usage.

The table shows that this region is rich with Trees Fruits and small fruits. These plants have economic importance and that are required in the global market are: Vaccinium myrtillus, Mallus sylvestris, Crataegus monagina, Cornus mas, Castanea sativa, Juglans regia, Rubus idaeus, Rosa canina etc. With MAP are also taking other authors as Rexhepi F.(2003), Millaku F. (2009) and have concluded that Kosovo has been having with the MAP. But their meeting was not done properly so some plants not found some are in danger of extinction.Plants that are shown in photo are plants which are mostly collected. But some of them endangered by unfair collection.

Tab. 1. Table with plant names and usable organs

\begin{tabular}{|l|l|l|l|l|l|}
\hline Nr. & Latin name & Organ & Nr. & Latin name & Organ \\
\hline 1 & Alnus glutinisa & Cortex & 15. & Origanum vulgare & Plant \\
\hline 2 & Betua pendula & Leaf & 16. & Papaver rhoeas & Fruit \\
\hline 3 & Cornus mas & Fruit & 17. & Prunus spinosa & Fruit \\
\hline 4 & Corylus avellana & Fruit & 18. & Prunus avium & Fruit \\
\hline 5 & Crataegus monogyna & (Fl-leaf) Fruit & 19. & Robinia pseudoacacia & Flower \\
\hline 6 & Fragaria vesca & Fruit & 20. & Rosa canina & Fruit \\
\hline 7 & Fragaria mochata & Fruit & 21. & Rubus fruticosus & Fruit \\
\hline 8 & Fraxinus ornus & Flower & 22. & Rubus idaeus & Fruit \\
\hline 9 & Juniperus communis & Fruit & 23. & Salix alba & Cortex \\
\hline 10 & Juniperus nana & Fruit & 24. & Sambucus nigra & Flower \\
\hline 11 & Juniperus oxycedrus & Fruit & 25. & Thymus sp. & Plant \\
\hline 12 & Juglans regia & Fruit & 26. & Tilia cordata & Flower \\
\hline 13 & Malus sylvestris & Fruit & 27. & Urtica dioica & Plant \\
\hline & Orchis morio & Bulb. & 28. & Vaccinium myrtillus & Fruit \\
\hline
\end{tabular}




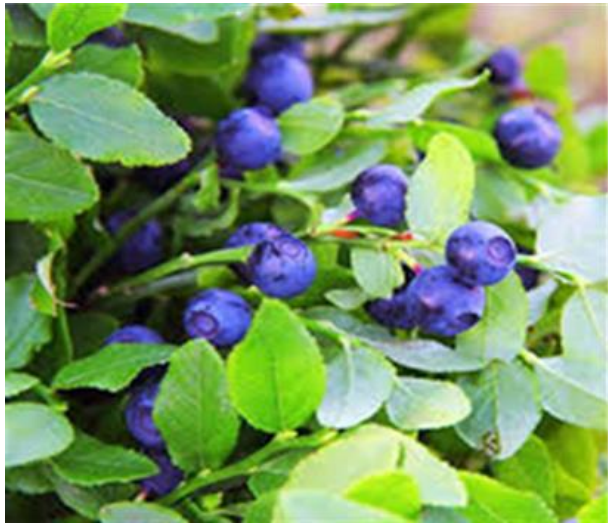

Fig. 3 Vaccinium myrtillus

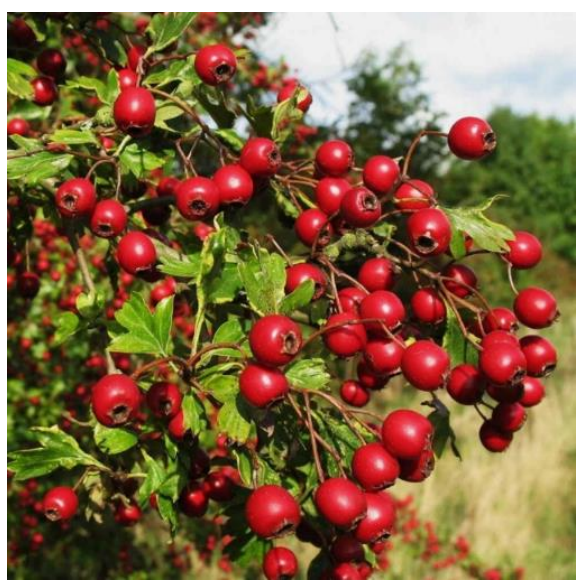

Fig.5. Crataegus monogyna

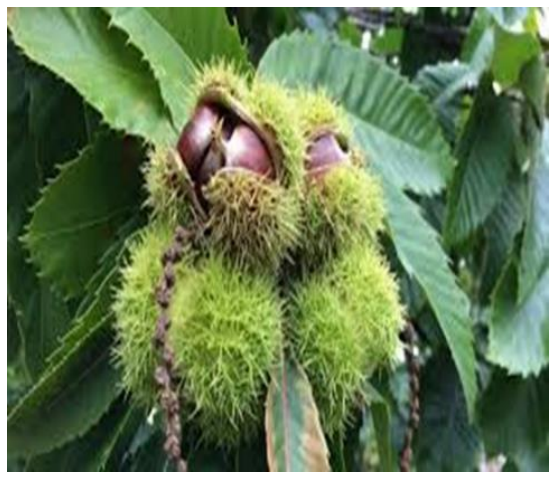

Fig. 7. Castanea sativa

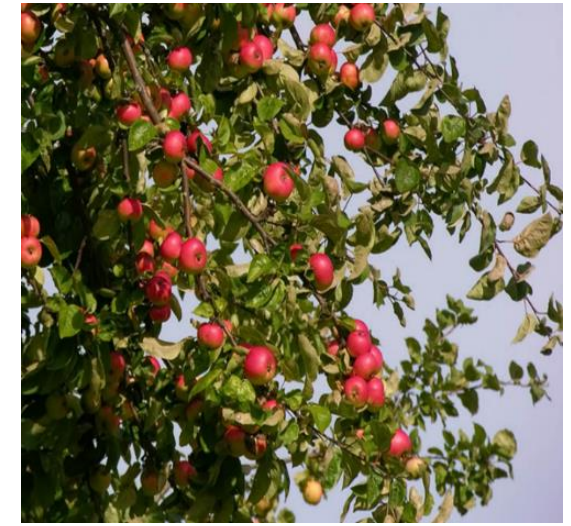

Fig.4. Malus sylvestrie

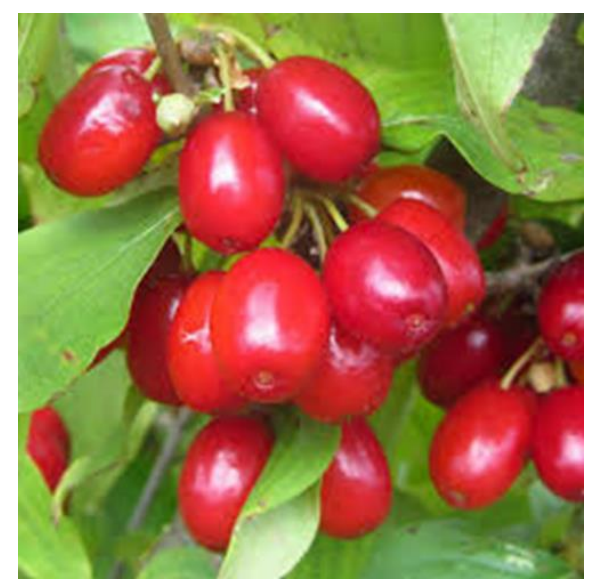

Fig.6. Cornus mas

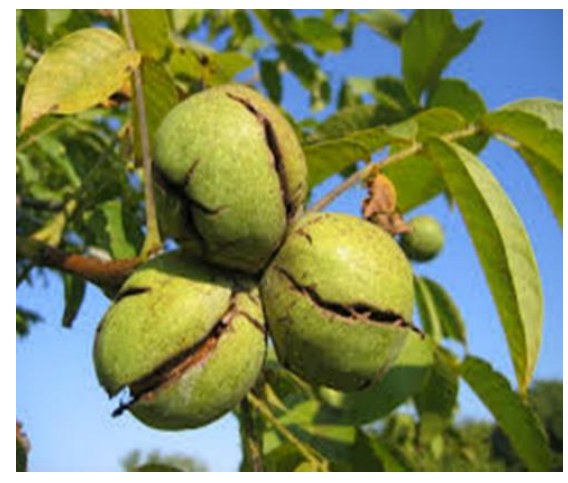

Fig. 8. Juglans regia 


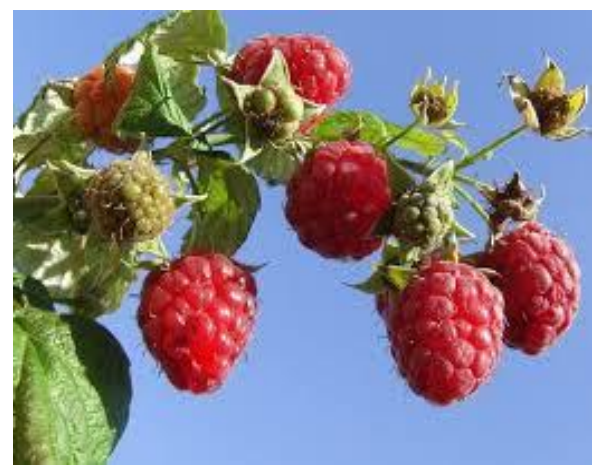

Fig. 9. Rubus ideaeus

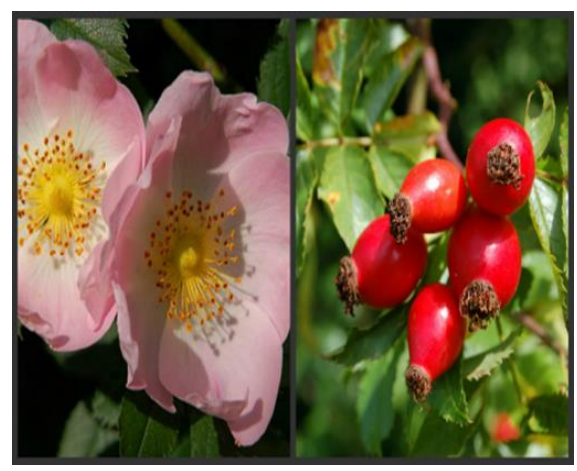

Fig. 10. Rosa canina

\section{CONCLUSIONS}

Once we have explored MAP have found that plants were seriously damaged by carelessly during the meeting, as grazing and burning of forests and pastures. Substantial damage to public property has had. Recommend measures to be taken by The Ministry of Environment for the protection of nature and the ministry of agriculture for the protection of MAP. People who do the collecting plants licensed and be notified of MAP collection that day by day their poor fund.

\section{REFERENCES}

1. Aichele, D., Golte, M. - Bechtle. (1993): Wildëachsende Blutepflanzen Mitteleuropas, Franckh - Kosmos, Stuttgart.

2. Demiri, M. (1983): Flora ekskursioniste e Shqipërisë, Shtëp. Bot. Libri Shkollor, Tiranë.

3. Josifovič, M. (ured.) (1970 - 1986): Flora SRS I-VI \& IX-X, SANU, Beograd.

4. Krasniqi, E., Rexhepi, F., Millaku, F. (2008): „Ndikimi i faktorit antropogjen në pyjet e dushkut në Kosovë“, Botim i veçantë për Tryezën Shkencore: „Mjedisi i KosovësResurset dhe faktori njeri“, ASHAK, pp. 81- 99, Prishtinë.

5. Krasniqi, F. et al. (2003): Fjalor i emrave të bimëve (Latinisht, Shqip, Anglisht, Gjermanisht, Frengjisht), ASHASH - IKB, Tiranë \& ASHAK - Seksioni i Shkencave të Natyrës, Prishtinë.

6. Millaku, F. (2009). Universiteti i Prishtinës FSHMN Departamenti I Biologjisë: , Inventarizimi i BMA dhe PFE është financuar nga projekti "Promovimi i Hortikulturës në Kosovë”, i zbatuar nga: Inter cooperation.

7. Millaku, F., Heiselmayer, P., Rexhepi, F., Krasniqi, E., Eichberger, Ch., Haziri, A. (2008) „Endemic, steno-endemic and relict plants in serpentines of Kosova”, Sauteria 16, 2008, pp. 149-162, Salzburg.

8. Paparisto, K., Demiri, M., Mitrushi, I., Qosja, Xh. (1988): Flora e Shqipërisë 1, (Akademia e Shkencave të RPSSH, Qendra e Kërkimeve Biologjike), Tiranë.

9. Paparisto, K., Demiri, M., Mitrushi, I., Qosja, Xh., Vangjeli, J. (1992): Flora e Shqipërisë 2, (Akademia e Shkencave të RSH, Qendra e Kërkimeve Biologjike), Tiranë.

10. Qosja, Xh., Paparisto, K., Demiri, M., Vangjeli, J., Ruci, B. (1996): Flora e Shqipërisë 3 , (Akademia e Shkencave të RSH, Qendra e Kërkimeve Biologjike), Tiranë.

11. Rexhepi, F. (2003): Bimët mjekësore, FSHMN, USAID - KBS Prishtinë 